\title{
Törökország információs befolyása az Európai Unió államaiban: a puha hatalomtól a fortélyos hatalomig? ${ }^{1}$
}

\begin{abstract}
A tanulmány Törökország információs befolyását vizsgálja az Európai Unióban. Az elemzés az információs célra is használható török intézményrendszer bemutatására összpontosít. Rámutat, hogy a rezsimbiztonsági megfontolások szerepének felerősödésével párhuzamosan a török külpolitika a puha eszközöktől a fortélyos eszközök alkalmazása felé tolódott el. Ez azonban eredményét tekintve nem Törökország befolyásának kiterjesztéséhez, sokkal inkább annak visszaszorulásához vezetett az Európai Unióban.
\end{abstract}

Kulcsszavak: Törökország, Európai Unió, információs befolyás, puha hatalom, fortélyos hatalom

Pénzváltó Nikolett: The Information Influence of Turkey in the States of the European Union: From Soft Power to Sharp Power?

The study examines the information influence of Turkey in the European Union. The analysis focuses on giving an overview of the Turkish institutional system which can be used for information purposes. The article points out that in parallel with the increasing role of regime security considerations, the use of soft power tools in the Turkish foreign policy has shifted toward sharp power tools. Due to this shift, however, Turkey has not extended, but rather limited its influence in the EU.

Keywords: Turkey, European Union, information influence, soft power, sharp power

\section{Bevezetés}

Az államok különböző stratégiákat és taktikákat alkalmaznak, hogy befolyásolják más országok döntéshozóinak és/vagy közvéleményének percepcióit. Ez nem egyedi és nem is újszerü jelenség. Biztonságpolitikai szempontból azonban kulcsfontosságú, hogy felismerjük és megértsük ezeket a külső befolyásolási törekvéseket.

Bár Törökország a NATO tagja és az Európai Unió tagjelölt állama, az utóbbi években - az egyre autoriterebb török belpolitika és az egyre önállóbb török külpolitika mintegy következményeként - nőtt a feszültség Ankara és nyugati szövetségesei között. A török kormány az európai államokat hibáztatja, amiért nem elég szolidárisak Törökországgal

\footnotetext{
Az Innovációs és Technológiai Minisztérium ÚNKP-19-3-I-NKE-19 kódszámú Új Nemzeti Kiválóság Programjának szakmai támogatásával készült.
} 
a terrorizmus elleni harcában ${ }^{2}$ és a menekültkérdés kezelésében. A Nyugat ezzel egy időben autoriter berendezkedése miatt bírálja a török rezsimet.

A tanulmány Törökország információs befolyását vizsgálja az Európai Unió (a továbbiakban: EU) államaiban. Feltárja az állami irányítású török információs befolyásolási törekvéseket, és értékeli hatásukat. Az elemzés a folyamatban részt vevő, információs célra is használható török intézményrendszer bemutatására összpontosít. Földrajzi értelemben a tanulmány az Európai Unió államainak vizsgálatára korlátozódik, és egy európai perspektívát vázol fel, ugyanakkor az EU összehasonlítása más térségekkel, különösen a török és/vagy muszlim többségü népességgel rendelkezö területekkel (mint például Közép-Ázsia vagy a Közel-Kelet) hasznos jövőbeli kutatási irányként szolgálhat. A nagy létszámú nyugat-európai török diaszpóra a téma kutatásának külön relevanciát ad.

\section{Elméleti és fogalmi keret: a puha hatalomtól a fortélyos hatalomig?}

A „sharp power” (fortélyos hatalom³) fogalmát Christopher Walker és Jessica Ludwig vezette be 2017-ben. ${ }^{4}$ Megkülönböztették a fogalmat a Joseph Nye által széles körben ismertté tett „puha” és „kemény” hatalomtól. Lényegét tekintve a kemény hatalom kényszerítésen (rendszerint katonai és gazdasági kényszerítő eszközökön), míg a puha hatalom vonzalmon alapul (amely vonzerő eredhet egy ország politikai értékeiből, kultúrájából és külpolitikájából). Walker és Ludwig ehhez képest a következöképpen különíti el a fortélyos hatalom fogalmát: az autoriter rezsimek „nem szükségszerüen arra törekszenek, hogy "megnyerjék az emberek szívét és elméjét«, ami a puha hatalmi törekvések gyakori hivatkozási alapja, helyette megpróbálják irányítani a célközönségüket az őket elérő információ manipulálásán vagy megmérgezésén keresztül”. ${ }^{5}$ Más szóval, a fortélyos hatalmi kezdeményezések „a manipuláció és cenzúra eszközei, nem az egyszerü vonzalomé”. ${ }^{6} \mathrm{~A}$ szerzők azt is megjegyzik, „a fortélyos hatalmi törekvések nagyrészt álcázáson alapulnak - az állami irányítású projekteket úgy állítják be, mintha a kereskedelmi média vagy alulról szerveződő egyesületek munkája lenne, például helyi szereplőket használnak a külföldi propaganda csatornájaként és a külföldi manipuláció eszközeként"?

A puha és a fortélyos hatalmat ezzel együtt nem mindig lehet élesen elkülöníteni. Ahogyan J. Michael Cole fogalmaz, egy ország hatalmának puha és fortélyos elemei „nem zárják ki kölcsönösen egymást, és nem is mondanak ellent egymásnak. Valójában inkább erösítik egymást." A török információs befolyásolási eszköztárnak is vannak puha és fortélyos, nyílt és rejtett szándékkal rendelkező elemei. A tanulmánynak nem célja, hogy éles

\footnotetext{
Ezt a harcot Ankara jelenleg elsősorban a török állami szervek által Fethullahista Terrorszervezetnek (röviden FETÖnek) nevezett Gülen-mozgalom, valamint a Kurdisztáni Munkáspárt, ismertebb nevén a PKK ellen folytatja.

A magyar fordítással ebben a cikkben találkoztam először: GYőri Lóránt - KREkó Péter: Az orosz „fortélyos hatalom” felemelkedése az információs térben, Élet és Irodalom, 63. évf., 2019/19.

4 Christopher Walker - Jessica Ludwig: From ,Soft Power' to ,Sharp Power: Rising Authoritarian Influence in the Democratic World, [online], 2017. Forrás: National Endowment for Democracy [2020. 04. 27.]

WALKER-LUDWIG: i. m., 13.

WALKER-LUDWIG: $i . m$., 18 .

WALKER-LUDWIG: i. m., 23.

J. Michael Cole: The Hard Edge of Sharp Power. Understanding China's Influence Operations Abroad, [online], 2018, 10. o. Forrás: MacDonald Laurier [2020. 04. 27.]
} 
határvonalat húzzon a kettő közé. Mindkettő rendelkezésre áll az államok számára, számos esetben ráadásul ugyanazokon az intézményeken keresztül is gyakorolhatók, ezért együttes vizsgálatuk indokolt.

Információs befolyásolási törekvéseken a tanulmányban olyan állami kezdeményezésű törekvéseket értünk, amelyek célja, hogy befolyásolja emberek nagy tömegeinek viselkedését a kívánt végkimenetel elérése érdekében, vagyis hatalmat gyakoroljon információk menedzselésén keresztül. Az információt különböző módokon és eszközökkel lehet irányítani, például egy ország értékeinek és eredményeinek népszerüsítése (puha eszközök) ugyanúgy idetartozik, mint a dezinformációs műveletek vagy az öncenzúrát eredményező politikai nyomásgyakorlás (fortélyos eszközök).

\section{A török információs befolyás célcsoportjai és céljai}

Az EU-n belül folytatott török információs befolyásolási törekvéseknek két közvetlen célcsoportja van: az európai állampolgárok és döntéshozók; valamint a török diaszpóra. Két további, közvetett célcsoportot is azonosíthatunk: Ankara igyekszik pozitív képet kialakítani magáról egyrészt a törökországi választópolgárok, másrészt az Európán kívüli, elsősorban iszlám világ előtt (Törökország régóta szeretné magát az iszlám világ vezetőjének szerepében feltüntetni - mérsékelt sikerrel). Ezt pedig nem csupán a tetteivel, hanem információk menedzselésén keresztül is teszi.

Milyen fő célokat igyekszik Ankara elérni? Egyik oldalról azáltal, hogy Törökországot pozitív színben tünteti fel, segíti a török érdekek érvényesítését, előmozdítja a két- és többoldalú együttmüködést. Ez eredményét tekintve megnyilvánulhat akár abban, hogy több európai turista utazik Törökországba, vagy éppen abban, hogy a török kormány támogatást és legitimációt kap európai államoktól egyes politikáinak végrehajtásához, legyen szó akár a szíriai intervencióról vagy az európai uniós csatlakozási folyamat előmozdításáról. Másik oldalról, az információ tartalmának és áramlásának szabályozása hozzájárulhat a török rezsim stabilitásának megőrzéséhez. A politikai értelemben érzékeny ügyek kommunikációjának ellenőrzés alatt tartása, a kritikus hangok elhallgattatása, illetve a Nyugat hiteltelenítése belpolitikai szempontból mind hasznos, hiszen nehezítik a kormányzó elit hatalmának aláásását, illetve legitimálják a rezsimet.

Törökország puha hatalmát az európaiak szemében 2013-ig, a Gezi parki tüntetésekig éppen az ország demokratikus és szekuláris jellege adta. Ahogyan azonban a török rezsim egyre autoriterebbé vált és egyre nagyobb teret engedett az iszlámnak, ${ }^{9}$ úgy csökkent Ankara vonzereje, ezzel puha hatalmi képességei az EU-n belül. Ezzel párhuzamosan a rezsimstabilitás fenntartásának igénye egyre erősebbé vált. A politika eltolódott a puha eszközöktől a fortélyos eszközök alkalmazása felé. Érdemes ugyanakkor megjegyezni azt is, hogy míg Európában Törökország puha hatalma csökkent, a világ más részein, különösen az iszlám világban Ankara népszerüségét növelte a Nyugattal szembeni konfliktusvállaló magatartás és egy, a nyugatival szembeni alternatív normarend propagálása.

\footnotetext{
Erről a folyamatról bővebben lásd EGEREsi Zoltán - PÉNZvÁLTó Nikolett: Az AKP útja az elnöki rendszerről szóló népszavazásig: rezsimépítés Törökországban (2002-2017), Nemzet és Biztonság, 2017/3, 80-109. o.
} 


\section{Az európai török diaszpóra}

Ami a török diaszpórát illeti, az EU-ban élő törökök elsősorban szavazataik miatt váltak a török információs befolyásolási törekvések egyik fö célcsoportjává. A 2014-es elnökválasztás óta a külföldön élő török állampolgárok leadhatják szavazataikat a lakóhelyük szerinti ország nagykövetségein vagy konzulátusain. Ez összesen több mint hárommillió szavazati joggal rendelkező törököt jelent (e választópolgároknak mintegy fele Németországban él). Az EU-ban élő törökök számáról nincsenek pontos és naprakész adataink, arról azonban igen, hányan szavaztak a 2018-as török parlamenti és elnökválasztáson. A lista eleje a következőképpen alakult: Németországban 651 ezer, Franciaországban 158 ezer, Hollandiában 120 ezer, Belgiumban 75 ezer, Ausztriában 51 ezer török állampolgár adta le a voksát. ${ }^{10}$ Ez a nagyságrend önmagában magyarázza, miért vált a diaszpóra a török politikai kampányok részévé.

A török diaszpóra és az anyaország, illetve a befogadó ország kapcsolata azonban ennél jóval összetettebb. ${ }^{11}$ Itt most csak két elemet emelünk ki. Az első, amit látni kell, hogy a diaszpóra egyszerre tölti be a célcsoport és az eszköz szerepét. A diaszpórán keresztül lehetőség van nyomást gyakorolni, illetve befolyásolni a fogadó ország közvéleményét és politikáit. Intézményi szinten a 2010-ben létrehozott Külhoni Törökök és Rokon Népek Elnökségét (YTB) kell megemlítenünk, amely szervezet többek között a török diaszpóra nyelvének és identitásának megőrzéséért dolgozik. Látnunk kell továbbá azt is, hogy az európai török diaszpóra messze nem egységes. Sőt, az egyik legnagyobb konfliktusforrást napjainkban éppen az jelenti, hogy a törökországi társadalom rendkívüli mértékủ polarizációja az európai diaszpóra körében is leképeződik. A politikai törésvonalak mellett a vallási és etnikai feszültségek ugyanolyan kihívást jelentenek. A török állampolgársággal rendelkezö, illetve Törökországból kivándorolt/elmenekült alevik és kurdok ugyanúgy saját érdekeik mentén igyekeznek befolyásolni az erurópai közvéleményt, az információs szférában is, mint a török kormány. A kisebbségi jogok iránti európai érzékenységet kihasználó csoportok lobbitevékenysége meglehetősen sikeres, ami rendszeres összeütközéshez vezet Ankara és egyes európai uniós tagállami kormányok között. Ez az elemzés kizárólag a török kormány (illetve kormánypárt) információs befolyását, ehhez alkalmazott intézményrendszerét vizsgálja. Az említett vallási és etnikai kisebbségi csoportok, illetve a kormányzó Igazság és Fejlődés Pártján (AKP) kívüli többi török párt EU-n belüli információs befolyásolási törekvéseinek vizsgálata kitenne, egy vagy inkább több különálló elemzést.

\section{A török információs befolyás intézményrendszere az EU államaiban}

A tanulmány további része az EU-ban megjelenő török állami információs befolyásolásban részt vevő legfontosabb intézményeket mutatja be. A lista nem kimerítö, törekszik azonban egy széles spektrumot felölelni. A bemutatott intézmények között szerepel NGO

10 Cumhurbaşkanı Seçimi ve 27. Dönem Milletvekili Genel Seçimi Sonuçları, [online], 2018. Forrás: T.C. Yüksek Seçim Kurulu [2020. 04. 27.]

11 Erről bővebben lásd: EgEREsi Zoltán: A vendégmunkások hazautalásaitól a nemzetközi lobbiig: Törökország és a török diaszpóra kapcsolata. Kisebbségkutatás, 24. évf., 2015/2, 73-97. o. 
(UID), think tank (SETA), kormányzati ügynökség (TIKA), kulturális intézet (Yunus Emre Intézet), oktatási intézmény (Maarif Alapítvány), vallási szervezet (Diyanet és külföldi szervezetei), gazdasági érdekképviseleti szervezet (MÜSİAD), nacionalista csoport (Osmanen Germania), politikai pártok, valamint médiumok és a közösségi média (TRT, Anatólia Hírügynökség, szappanoperák, „trollok”). A cikk nem vizsgálja külön a török Nemzeti Hírszerző Szolgálat (MİT) tevékenységét, noha tény, hogy a fortélyos hatalom, illetve az információs befolyásolási törekvések sok esetben átfedést mutatnak a hagyományos hírszerző tevékenységgel. Nem vizsgálunk külön egyéneket (például politikusokat) sem; az elemzés intézményi fókuszú.

\section{Nemzetközi Demokraták Uniója (UID)}

Az Európai Török Demokraták Unióját (UETD) 2004-ben alapították. A szervezetet 2018 májusában átnevezték Nemzetközi Demokraták Uniójává (UID). Az UID hivatalosan egy NGO, amely nem kötődik formálisan egyetlen politikai párthoz sem. A gyakorlatban azonban szoros kapcsolatban áll Recep Tayyip Erdoğan török elnökkel, és a tevékenysége alapján a török kormány lobbiszervezetének tekinthetö. A német szövetségi alkotmányvédelmi hivatal (BfV) 2017-es jelentésében úgy utal az UETD-re, mint „a kormányzó Igazság és Fejlődés Pártjának nem hivatalos külföldi szervezete". ${ }^{12}$ Az elmúlt években az UID több nagyszabású rendezvényt szervezett a török rezsim számára fontos ügyekben. Németországban például részt vettek a török elnökválasztási kampány szervezésében, Párizsban pedig az UID szervezésében mutatták be a török köztársasági elnöki hivatal kommunikációs igazgatósága által készített, a Gülen-mozgalom ${ }^{13}$ „igazi arcát” bemutató, A Hálózat címü filmet. ${ }^{14}$ Tisztviselőik időnként televíziós müsorokban is megszólalnak. Az AKP politikusai és kormánypárti szakértők gyakran látogatják meg a szervezet irodáit, ahol különböző rendezvényeket tartanak. ${ }^{15} \mathrm{Az}$ EU-n belül az UID-nak Ausztriában, Belgiumban, Csehországban, Dániában, Finnországban, Franciaországban, Hollandiában, Magyarországon, Németországban, Olaszországban és Svédországban van irodája.

\section{Politikai, Gazdasági és Társadalmi Kutatási Alapítvány (SETA)}

Az Ankara központú think tank, a Politikai, Gazdasági és Társadalmi Kutatási Alapítvány, ismertebb nevén SETA, 2005-ben jött létre. Alapító igazgatója İbrahim Kalın (2005-2009), aki jelenleg elnöki szóvivőként, illetve Erdoğan tanácsadójaként tevékenykedik. Kalınon kívül azonban több egykori és jelenlegi SETA-tagot is szoros szálak füznek a török kormány-

12 Verfassungsschutzbericht 2017, [online], 2018. Forrás: Bundesministerium für Innern, für Bau und Heimat [2020. 04. 27.]

13 Fethullah Gülen török hittudós, aki 1999 óta az Egyesült Államokban él. A török hatóságok Gülent vádolják a 2016-os törökországi puccskísérlet elkövetésével. Gülen a korábbi években széles körű oktatási és alapítványi hálózatot épített ki Törökországon belül és kívül. Erdoğan és Gülen kapcsolata 2013-ig jónak volt mondható, érdekeik a szekuláris, kemalista elit háttérbe szorítását illetően egybeestek. A hatalmi harc közöttük 2013-ban indult meg.

14 İslam DoĞRU: New York’ta ve Paris’te FETÖ’nün gerçek yüzü anlatıldı, [online], 2019. 07. 12. Forrás: Anadolu Ajansı [2020. 04. 27.]

15 A szervezet tevékenységéről bővebben lásd a 2017-es beszámolóját: Faaliyet Raporu, [online], 2017. Forrás: UETD [2020. 04. 27.] 
hoz, illetve többen kerültek közülük kormányzati pozíciókba. A SETA-nak Törökországon kívül Washingtonban, Kairóban, Brüsszelben és Berlinben van irodája. A think tank rendszeresen szervez különböző rendezvényeket, jellemzően kerekasztal-beszélgetéseket, valamint széles körű publikációs tevékenységet folytat, elsősorban ezen keresztül befolyásolja a tudományos és társadalmi diskurzust. A könyvek, tanulmányok, véleménycikkek török és angol nyelven jelennek meg. ${ }^{16}$ Kutatóik azonban jellemzően nemcsak saját intézményükben, hanem más török lapokban is publikálnak. ${ }^{17}$

\section{Yunus Emre Intézet}

Az első Törökországon kívüli Yunus Emre Intézetet Szarajevóban hozták létre 2009-ben. ${ }^{18}$ Az EU-n belül ma Párizsban, Madridban, Rómában, Amszterdamban, Brüsszelben, Kölnben, Berlinben, Bécsben, Varsóban, Budapesten, Zágrábban és Bukarestben van irodájuk. ${ }^{19} \mathrm{~A}$ Yunus Emre Intézeteket a német Goethe Intézet vagy a British Council mintájára hozták létre, céljuk a török kultúra népszerüsítése. Tevékenységeik közé tartozik a töröknyelv-oktatás, rendezvények (kiállítások, tanfolyamok, filmestek) szervezése, valamint a kulturális és tudományos diplomácia (van például egy csereprogramjuk egyetemi oktatók és kutatók számára). A Yunus Emre Intézet a török puha hatalom fő letéteményese, az intézetek programjai rendkívül népszerűek. A szervezet elnöke egy interjúban kiemelte, az intézet erőssége, hogy a puha hatalom akkor is müködik, amikor a politika holtpontra jutott: példának Egyiptomot hozta, ahol a két ország közötti súlyos politikai ellentétek ellenére a Yunus Emre Intézet aktívan jelen tudott lenni. ${ }^{20}$ Mivel azonban az intézetek költségvetése állami, nem kerülhetik ki teljesen a politikát. Több országban is részt vettek például az ellentmondásos törökországi puccskísérletet bemutató fotókiállítás szervezésében, illetve a Gülen-mozgalom hiteltelenítésében.

\section{Török Együttmúködési és Koordinációs Ügynökség (TiKA)}

A Török Nemzetközi Együttmüködési és Fejlesztési Ügynökséget 1992-ben alapították. 2011-ben átszervezték és átnevezték Török Együttmüködési és Koordinációs Ügynökséggé, rövidített neve azonban maradt továbbra is TiKA. Az EU-n belül Budapesten, Zágrábban és Bukarestben vannak irodái. A Yunus Emre Intézetek mellett a TiKA a török puha hatalom másik legfontosabb eszköze. Tevékenysége a fejlesztési együttmüködésre és az oszmán müemlékek helyreállítására összpontosít. Hangsúlyozza a közös történelmi és kulturális szálakat, valamint pozitív képet sugároz Törökországról. Magyarország esetében a TİKA az utóbbi években támogatta például a szigetvári Magyar-Török Barátság Park felújítását,

16 A SETA gondozásában jelenik meg például minden évben 2015 óta az Európai Iszlamofóbia Jelentés. A jelentés 2019ben nagy visszhangot váltott ki például Dániában, lásd: Outrage in Denmark after EU-funded report brands it, Islamophobic', [online], 2019. 11. 06. Forrás: The Local [2020. 04. 27.]

17 Barış TerkoĞLu: Saray'daki 'SETA lobisi’ni ne zaman konuşacağı?, [online], 2019. 07. 08. Forrás: Cumhuriyet [2020. 04. 27.]

18 Yunus Emre a 13-14. század fordulóján élt török, szúfi költő.

19 Yunus Emre Enstitüsü, [online], 2020. Forrás: yee.org.tr [2020. 04. 27.]

20 Ali ÜnAL: Yunus Emre Institute Head Ateş: As an element of soft power, our aim is to introduce Turkey, its culture to the world, [online], 2017. 07. 24. Forrás: Daily Sabah [2020. 04. 27.] 
Szulejmán szultán türbéjének régészeti feltárását, de pénzügyileg támogatták például a szegedi Krúdy Gyula Vendéglátóipari és Szakácsképző Szakképző Iskola tankonyhájának a felújítását, illetve a budapesti Semmelweis Egyetem Gyermekgyógyászati Klinikájának intézményi kapacitásbővítését, továbbá könyvek fordítását és kiadását. ${ }^{21} \mathrm{~A}$ TİKA-nak az egykori oszmán birodalmi, illetve iszlám területeken, valamint a fejlődő világban jelentősebb a befolyása.

\section{Maarif Alapítvány}

A Maarif Alapítvány az EU-n belül első iskoláját Romániában nyitotta meg 2019-ben. 2019 őszén a budapesti iskola is aktív státuszt kapott, a tanítás azonban várhatóan csak 2020 őszén kezdődik el. ${ }^{22} \mathrm{Az}$ EU területén kívül a Maarif Alapítvány jóval aktívabb: 34 országban 291 iskolát müködtetnek, ahova 28703 tanuló jár. ${ }^{23}$ A Maarif Alapítványt 2016-ban hozták létre, a Gülen-mozgalom elleni harc részeként. Erdoğan igyekszik világszerte átvenni az irányítást a gülenista iskolák fölött, vagy pedig bezáratni azokat. A török kormány eddig 18 országban összesen 217 iskolát vett át (például Szomáliában, Maliban vagy Afganisztánban). Európában az alapítvány több helyről kapott kritikát, olyan beszámolók miatt, amelyek szerint céljai politikaiak, illetve iszlamista kapcsolatokkal rendelkezik. ${ }^{24}$

\section{Vallási Ügyek Elnöksége (Diyanet)}

A török Vallási Ügyek Elnöksége, ismertebb nevén a Diyanet egy államigazgatási szerv, amelyet még 1924-ben, a Török Köztársaság megalapítását követően hoztak létre. Az AKP 2002-es hatalomra jutása óta a Diyanet szerepe megnőtt; bürokratikus testületből a politikai hatalomgyakorlás eszközévé vált. ${ }^{25} \mathrm{~A}$ Diyanet Törökországon belül összesen több mint 85 ezer, Törökországon kívül pedig további 2000 mecsetet felügyel:; ${ }^{26}$ elkészíti a pénteki prédikáció szövegét az összes mecset számára, Korán-tanfolyamokat tart, saját televíziós csatornát üzemeltet, kérés esetén pedig vallási iránymutatást biztosít. Több mint 150 ezer embert foglalkoztat, közéjük tartozik az összes török imám. A Diyanet tevékenységét a Török Diyanet Alapítvány (TDV) egészíti ki. Az alapítványi forma nagyobb rugalmasságot nyújt a pénzügyek területén.

A Diyanet az EU országainak döntő többségében tart fenn vallási szolgálati tanácsadói, koordinációs és/vagy attaséirodát. ${ }^{27}$ A Diyanetnek emellett számos európai országban van helyi szervezete, amelyek csupán névlegesen autonóm egyesületek. Az elsőt 1984-

21 Bővebben a magyarországi projektekről lásd: Magyarország. Projektek és tevékenységek 2014-2015, [online], 2015. Forrás: TİKA [2020. 04. 27.]

22 Maarif Általános Iskola és Gimnázium, [online], 2019. Forrás: Oktatási Hivatal [2020. 04. 27.]

23 Abdullah Bozkurt: Erdoğan's long arm Maarif is educating 30,000 students in 34 countries, [online], 2019. 08. 16. Forrás: Nordic Monitor [2020. 04. 27.]

24 BOZKURT: i. m.

25 A Diyanet szerepével kapcsolatos jogi kérdőjelekről lásd: SiskA Katalin: A Vallási Ügyek Elnökségének jogi anomáliája a Török Köztársaságban, Pro Publico Bono - Magyar Közigazgatás, 2017/3, 118-131. o.

26 Meltem Özgenç: Top cleric delivers Friday sermon in Mardin, [online], 2016. 02. 05. Forrás: Hürriyet Daily News [2020. 04. 27.]

27 Yurt Dışı Temsilcilikler, [online], 2020. Forrás: Diyanet İşleri Başkanlığı [2020. 04. 27.] 
ben Németországban hozták létre. Németországban és Franciaországban Vallási Ügyek Török-Iszlám Uniója (DİTİB) néven müködik a szervezet, de Ausztriában például ATİB, Hollandiában pedig HDV vagy ISN rövidítéssel ismert. A Diyanet befolyása az egyes európai országokban eltérő. Németországban és Hollandiában a legtöbb mecsetet összefogó ernyőszervezet van a kezében: közel 800, illetve 143 mecsetet üzemeltetnek. 2013-ban Ausztriában 58, Belgiumban 65, Dániában 27 mecset kötődött a Diyanethez. ${ }^{28}$ E mecsetekbe a Diyanet küldi az imámokat, akik fizetését a török állam adja.

A kezdeti időszakban a török imámokat szívesen látták az európai államokban. Közös cél volt az iszlamista radikalizáció megakadályozása az európai muszlimok körében, illetve a keményvonalasabb, például szaúdi befolyás csökkentése. A jelenlegi török adminisztráció beavatkozása a diaszpóra hitéletébe azonban feszültségeket hozott a korábban sikeres együttmüködésbe. Az AKP-nak a török diaszpórára gyakorolt befolyása mellett arról is olvashatunk, hogy a török kormány szoros kapcsolatot épített ki más európai muszlim szervezetekkel, különösen a Muszlim Testvériséghez kötődőkkel. A támogatásért cserébe e hálózatok részt vesznek az AKP népszerüsítésében. ${ }^{29}$ A DİTİB-nek (és a többi társszervnek) az európai felfogás szerint politikailag semlegesnek kellene lennie, ez azonban jelenleg nem mondható el. A nyugati percepció szerint a Diyanet szerepe átalakult: míg korábban a politikai iszlám ellensúlyaként lépett fel, napjainkban többen vádolják őket politikai szerepvállalással, például az európai török állampolgárok - a Gülen-mozgalom állítólagos tagjai - utáni kémkedéssel. (A 2016-os puccskísérletet követően több európai imám ellen vizsgálat is indult.) ${ }^{30}$ A növekvő aggodalmakra válaszul elsősorban Németországban több javaslat is napirenden van. Ezek egyike a „mecsetadó” bevezetése, amelynek célja az lenne, hogy csökkentse a külföldi - potenciálisan radikális vagy antidemokratikus - finanszírozási források befolyását. Az iszlám intézmények így képesek lennének magukat finanszírozni, és valóban függetlenné válhatnának a külső állami befolyástól. ${ }^{31}$ Hasonló céllal vezetnék be az imámok helyi képzését is. ${ }^{32}$

\section{Független Iparosok és Üzletemberek Szövetsége (MÜSIAD)}

Meg kell említenünk a gazdasági és üzleti szférát is. A Független Iparosok és Üzletemberek Szövetsége (MÜSİAD) a kormányzó elithez közel álló szervezet, elsősorban a konzervatív, muszlim üzletembereket tömöríti. A törökországi puccskísérletet követően a MÜSİAD fokozta nyilvános diplomáciai tevékenységét azzal a céllal, hogy javítsa Törökország imázsát, hangsúlyozza az ország stabilitását és a demokrácia erejét, ezáltal elősegítse a gazdasági együttműködést, és növelje az országba irányuló befektetéseket. A korábban nem éppen európai orientációjáról ismert MÜSİAD az utóbbi években képviseleti irodát nyitott számos európai országban. Tevékenységét és céljait tekintve ugyanakkor a szervezetnek

\footnotetext{
28 Thijl Sunier - Nico Landman: Transnational Turkish Islam, Palgrave Pivot, 2014.

29 Lorenzo Vidino: Erdogan’s Long Arm in Europe, [online], 2019. 05. 07. Forrás: Foreign Policy [2020. 04. 27.]

30 Chase Winter: Turkish imam spy affair in Germany extends across Europe, [online], 2017. 02. 16. Forrás: DW [2020. 04. 27.]

31 Germany mulls introducing 'mosque tax' for Muslims, [online], 2018. 12. 26. Forrás: DW [2020. 04. 27.]

32 Zia WeIse: Wanted: Imams made in Germany, [online], 2019. 12. 17. Forrás: Politico [2020. 04. 27.]
} 
hasonló céljai voltak - tudniillik a török gazdasági lehetőségek javítása - az alapvetően eltérő világnézetet képviselö, szekuláris, nyugat-orientált TÜSİAD-dal. ${ }^{33}$

\section{Osmanen Germania}

A török ultranacionalista csoport, az Osmanen Germania 2015 áprilisában alakult meg. Bokszklubként hivatkoznak magukra, a német hatóságok azonban több tagjuk érintettségét felfedték különféle büncselekményekben. A motoros bandaként is emlegetett csoportnak becslések szerint 2500 tagja van Németországban, és további ezer Törökországban, Ausztriában, Svájcban és Svédországban. A német belügyminisztérium 2018 júliusában betiltotta az Osmanen Germaniát. ${ }^{34}$ Tényfeltáró riportok szerint a bandát szoros kapcsolat füzi az AKP politikusához, Metin Külünkhöz, aki Erdoğan közeli bizalmasa. Német rendőrségi nyomozás során fény derült rá, hogy az ultranacionalista csoport utasításokat és pénzt kapott Külünktől ahhoz, hogy elrettentésként fellépjenek Erdoğan kritikusaival és a kurdokkal szemben Németországban. Tagjai tüntetéseken is rendszeresen megjelentek. ${ }^{35}$

\section{Politikai pártok}

Az AKP politikai pártokat is támogat az EU bizonyos államaiban, amelyeken keresztül igyekszik a narratíváit népszerüsíteni. Franciaországban az Egyenlőség és Igazságosság Pártja (PEJ) 2015-ben alakult meg. Ausztriában 2016 óta működik az Új Mozgalom a Jövőért (NBZ) párt. Németországban a Német Demokraták Szövetsége (AD-Demokraten) 2016ban jött létre. Alapítója az UETD korábbi vezetője, Remzi Aru, aki Erdoğan támogatója. A párt azt követően alakult meg, hogy a német parlament az örmény népirtást elismerő határozatot fogadott el, mintegy reakcióként a döntésre. Azonban mindhárom említett párt marginálisnak tekinthető: a 2017-es parlamenti választásokon az országos szavazatoknak mindössze legfeljebb 0,1\%-át nyerték el. Hollandiában a DENK 2017-ben alakult meg. A DENK az eddigi legsikeresebb AKP-párti európai párt; az első „bevándorlópárt”, amely parlamenti helyeket tudott szerezni egy EU-s államban. A 2017-es parlamenti választáson három parlamenti helyet nyert el a 150 fős képviselöházban. ${ }^{36}$ Görögországban szintén létezik török párt, a Barátság, Egyenlőség és Béke Pártja (görögül KIEF, törökül DEBP), ez azonban még 1991-ben, jóval az AKP hatalomra kerülése előtt alakult. A 3\%-os parlamentbe jutási küszöböt azonban az utóbbi választásokon nem tudta átlépni, 2009-ben szerzett utoljára parlamenti mandátumot.

33 Derya Büyüktanır Karacan: Public Diplomacy Activities of TÜSİAD and MÜSİAD During the AK Party Era, Gazi Akademik Bakış, 11. évf., 2018/23, 73-98. o.

34 Osmanen Germania: Germany bans ethnic Turkish boxer gang, [online], 2018. 07. 10. Forrás: BBC News [2020. 04. 27.]

35 Chase Winter: Turkish AKP politician linked to Osmanen Germania boxing gang in Germany, [online], 2017. 12. 14. Forrás: DW [2020. 04. 27.]

36 Koen Damhuis: "The biggest problem in the Netherlands": Understanding the Party for Freedom's politicization of Islam, [online], 2019. 07. 24. Forrás: Brookings [2020. 04. 27.] 
Bulgária egyedi eset az EU-n belül abból a szempontból, hogy arányaiban Bulgáriában él a legnagyobb török közösség: a 2011-es népszámlálás adatai ${ }^{37}$ alapján 588313 fö, a lakosság közel 8,8\%-a vallotta magát töröknek. A bulgáriai török diaszpóra döntő része azonban nem rendelkezik török állampolgársággal. ${ }^{38}$ Ez magyarázza, hogy miért mindössze 1249 szavazatot adtak le Bulgáriában a 2018-as török választáson. ${ }^{39}$ A bulgáriai törökök legnagyobb pártja a Mozgalom a Jogokért és Szabadságért (bolgárul DPS, törökül $\mathrm{HÖH)} .^{40}$ A DPS jellemzően $10 \%$ körüli választási eredménnyel a mérleg nyelveként volt képes működni az utóbbi évtizedekben a bulgáriai politikában. A DPS kapcsolata azonban nem tekinthető szorosnak az AKP-val. 2015-ben a DPS több politikusa távozni kényszerült a pártból amiatt, mert túlságosan AKP-barát politikát folytattak. Ök alapították meg a Demokraták a Felelősségért, Szolidaritásért és Toleranciáért (DOST) elnevezésű pártot. A 2017-es választáson azonban a DOST nem tudta átlépni a parlamentbe jutáshoz szükséges 4\%-os küszöböt.

\section{Média}

A globális török médiajelenlét két legfontosabb intézményi eleme az Anatólia Hírügynökség (AA) és a Török Rádió és Televízió (TRT). Az AA 2014-ben azt a célt fogalmazta meg, hogy 2020-ra a világ top öt hírügynöksége közé kerüljön. Jelenleg 13 nyelven jelennek meg. A 2018 júliusában közvetlenül a török elnöki hivatal alá rendelt TRT 2015-ben indította el 24 órás angol nyelvü TRT World nevü nemzetközi televíziós hírcsatornáját, amelynek székhelye Isztambul, azonban Washingtonban, Londonban és Szingapúrban is van irodájuk. A cél a török perspektíva és narratívák terjesztése, az ország népszerüsítése, illetve a Nyugattal szemben bírálatok megfogalmazása. 2009 óta TRT Kurdi néven kurd nyelvü televíziós csatornát is müködtetnek - a csatorna elindításának mögöttes célja a 2004-től különböző európai államokból sugárzó, erősen kormánykritikus, a török álláspont szerint a PKK adójaként működő kurd nyelvü Roj TV befolyásának csökkentése volt. ${ }^{41}$

Az európai török diaszpóra megszólításának egyik eszköze a 2005-ben alapított Kanal Avrupa (Európa Csatorna) televíziós csatorna. 2013 óta müködik az AKP-párti avrupaturkgazetesi.com weboldal, amelynek célközönsége szintén az európai törökség. Az internetnek köszönhetően ugyanakkor török weboldalakhoz, internetes hírportálokhoz bárki, bárhonnan hozzáférhet, a törökországi kormányzati médiatúlsúly így az ország területén

372011 Population Census - main results, [online], 2011. Forrás: nsi.bg [2020. 04. 27.]

38 Ennek egyik fő oka, hogy a bulgáriai törökök döntő része nem bevándorlóként érkezett az 1960-as évektől kezdődően a megkötött munkaerö-egyezmények következtében, mint a nyugat-európai törökség, hanem már az Oszmán Birodalom idején is a mai Bulgária területén éltek.

39 A 2018-as választások eredménye elérhető: https://sonuc.ysk.gov.tr [2020. 04. 27.]. A bolgár esetben fordított előjelü a probléma: a török-bolgár viszonylatban az okoz rendszeresen feszültséget, hogy a Törökországban dolgozó, mintegy 200 ezer bolgár állampolgárt szervezetten, buszokkal szállították a törökök Bulgáriába, hogy azok leadhassák szavazatukat az etnikai török párt(ok)ra.

40 Egeresi Zoltán: Mozgalom a Jogokért és Szabadságért: egy etnikai párt útja az európai liberálisokhoz, Pro Minoritate, 2009. ősz, 175-189. o.

41 Bár 24 órás magyar nyelvű televíziós csatornája nincs, magyar nyelvű híroldala van a TRT-nek, valamint a 42 nyelven sugárzó Törökország Hangja Rádió (TSR) napi félórás magyar nyelvü adást is sugároz. 
kívül is hat. ${ }^{42} \mathrm{~A}$ nyomtatott média világszinten visszaszorult, néhányezres példányszámban azonban jelennek meg az EU-n belül török lapok. A legnagyobb és legismertebb napilap, a Hürriyet 1969-ben jelent meg először Németországban. A frankfurti nyomdát és kiadót 2013-ban zárták be.

A török információs befolyás eszközeként említhetők a török szappanoperák is. 2018ban Törökország 500 millió dollár értékben exportált szappanoperákat, amivel világviszonylatban a második volt az Egyesült Államok után. ${ }^{43} \mathrm{~A}$ törökök szerint ezek a müsorok már nem is szappanoperák, hanem egy különálló müfajt alkotnak, amit dizinek neveznek (a dizi törökül sorozatot jelent). ${ }^{44} \mathrm{Az}$ egyik legsikeresebb török televíziós sorozatot, a Muhteşem Yüzyllt (magyarul Csodálatos évszázad), ami Magyarországon Szulejmán néven volt adásban, 70 országban sugározták. A török dizik sikere azonban - 2008-tól egyre erősödő népszerüségük ellenére - a kezdeti években egyáltalán nem volt teljes mértékben összhangban a török kormánypárt céljaival. Maga Erdoğan például kifejezetten ellenségesen tekintett a Csodálatos évszázadra, még a müsor betiltásának lehetősége is felmerült. A legtöbb dizi értékrendje ugyanis túlságosan liberális volt az AKP konzervatív irányvonala számára. ${ }^{45}$

$\mathrm{Az}$ újabban megjelent török sorozatok egy része azonban már egyértelmű állami propagandacélokat szolgál. Két TRT-produkciót kell kiemelnünk: az Ertuğrul felemelkedése (Diriliş: Ertuğrul) és a Payitaht Abdülhamid című sorozatokat. Előbbi az Oszmán Birodalom felemelkedését meséli el (Ertuğrul fia Oszmán szultán, a birodalom alapítója), utóbbi középpontjában pedig az utolsó nagy oszmán szultán, II. Abdülhamid (uralkodott 1876-1909) áll. ${ }^{46} \mathrm{~A}$ kormányzati narratívában Abdülhamid példaképként jelenik meg. Egyrészt mint tekintélyelvű vezetö, másrészt mint „Törökország Atatürkkel szembeni iszlamista alternatívája" és történelmi inspirációs forrás. ${ }^{47} \mathrm{~A}$ török nagyság, valamint a Nyugattal való konfrontációtól vissza nem riadó ország képe mindkét sorozatban hangsúlyos.

\section{Hacktivista csoportok és kormányzati „trollok”}

Végezetül meg kell említenünk a különböző hacktivista csoportok és kormányzati „trollok" szerepét. Több török hacktivista csoport is tevékenykedett az EU államaiban AKPpárti agendával, köztük az Aslan Neferler Tim (ANT), a Turk Hack Team és az Akıncılar. ${ }^{48}$

42 PÉnzváLTó Nikolett: Dezinformációs és külső információs befolyás Törökországban, [online], SVKK Elemzések, 2019/24. Forrás: svkk.uni-nke.hu [2020. 04. 27.]

43 Turkish TV series attract audience from 146 countries, [online], 2019. 11. 13. Forrás: Hürriyet Daily News [2019. 11. 13.]

44 Didem TALI: An unlikely story: Why do South Americans love Turkish TV?, [online], 2016. 09. 08. Forrás: BBC News [2019. 11. 13.]

45 A török szappanoperák terjedése a rajongótábor növekedése mellett rendkívül sok ellenséges reakciót is kiváltott, azonban nem elsősorban az EU-ban. Ezeket a negatív reakciókat három kategóriába sorolhatjuk: egyrészt a konzervatív muszlimok fogalmaznak meg kritikát; másrészt az egykori oszmán területeken jelen van egyfajta „kulturális kolonializmus"-tól való félelem; harmadrészt pedig találkozhatunk tisztán politikai motivációjú korlátozásokkal is. Mindezek nyomán számos országban (Macedónia, Üzbegisztán, Kazahsztán, Pakisztán, Szaúd-Arábia) léptettek életbe tiltásokat a török sorozatokkal szemben.

46 Fatima Bнutтo: How Turkish TV is taking over the world, [online], 2019. 09. 13. Forrás: The Guardian [2019. 11. 13.]

47 Mustafa Akyol: Why is Turkey reviving an Ottoman sultan?, [online], 2016. 09. 29. Forrás: Al-Monitor [2020. 04. 27.]

48 Nem bizonyítható ugyanakkor minden kétséget kizáróan, hogy e csoportok bármelyike közvetlenül kötődne a török kormányhoz. 
Általában szolgáltatásmegtagadással járó túlterheléses, illetve honlaprongáló támadások kötődnek a nevükhöz. Az ANT például 2016 őszén Ausztria ellen intézett több támadást, többek között a bécsi repülőtér, az osztrák nemzeti bank, valamint a külügyminisztérium rendszerét támadták, mindezt bosszúból Bécs „törökellenes” politikájáért. ${ }^{49}$ A Turk Hack Team 2017 tavaszán Hollandia ellen indított müveletet (Hollanda Operasyonu). ${ }^{50}$ Az Akıncilar csoport pedig 2011-ben a francia szenátus weboldalát tette elérhetetlenné az örmény népirtási határozat elfogadása elleni tiltakozásként. ${ }^{51}$

Az AKP első, mintegy 6000 főből álló digitális egységét 2013 szeptemberében hozták létre. Azóta egyre többet lehet olvasni a párt által alkalmazott trollokról, illetve botnet támadásokról, amelyek a közösségi médián keresztül alakítják a török kormány érdekeinek megfelelően az embereket elérő információkat. 2019 októberében például az EU-szerte hangos tiltakozást kiváltó szíriai török katonai intervenció legitimálására indult egy, a kormányzati narratívával összhangban lévő Twitter-kampány, amelynek középpontjában a \#BabyKillerPKK hashtag volt. ${ }^{52}$

\section{Az információs tevékenység összehangoltsága}

A különféle információs csatornák közötti koordináció módjára, illetve a központi irányítás mértékére nincs rálátásunk. Az mindenesetre nagy bizonyossággal feltételezhető, hogy a lényegében minden fontos területen megfigyelhető központosító irányvonal a kommunikáció összehangolásában is megjelent, és a legfontosabb hatalmi központtá ezen a területen is a török elnök vált. Az elnöki rendszer törökországi bevezetését követően nem sokkal, 2018. július 24-én elnöki rendelettel létrehozták a Kommunikációs Elnökséget (İletişim Başkanlı̆̆ı) az elnöki hivatalon belül, amely meghatározó szerepet tölthet be a folyamatban. Nyilvános diplomáciával foglalkozó szervezeti egységének feladatai közé tartozik a nemzetközi közvélemény alakítása, az összehangolt kommunikáció a „török márka” népszerüsítésében részt vevő különböző intézményekkel, illetve a Törökországgal kapcsolatos propagandatevékenységek nyomon követése. ${ }^{53}$

\section{Összegzés és következtetések}

A tanulmány bemutatta azt az intézményrendszert, amelyet a török kormány használ információs befolyásolási törekvéseihez az Európai Unió államaiban. Kirajzolódott, hogy a török információs befolyásolási törekvések intenzitása eltérő az egyes országokban: az egykori oszmán birodalmi, illetve a nagy török diaszpórával rendelkező területeken erősebb a török jelenlét. Rámutattunk arra, hogy a török befolyásolási törekvések nem

49 Sarah Souli: Turkey's band of pro-Erdoğan hackers keep trolling Europe, [online], 2018. 03. 17. Forrás: Vice News [2020. 04. 27.]

50 Harrison VAN Riper: Turk Hack Team and the "Netherlands Operation”, [online], 2017. 03. 29. Forrás: Digital Shadows [2020. 04. 27.]

51 Tony ToDD: Turkish hackers avenge France's 'genocide bill', [online], 2011. 12. 27. Forrás: France 24 [2020. 04. 27.]

52 Bot-like Turkish accounts complement military operation in Syria, [online], 2019. 10. 06. Forrás: Medium [2019. 11. 02.]

53 İletişim Başkanlığı Teşkilatı Hakkında Cumhurbaşkanlığı Kararnamesi, [online], 2018. 07. 23. Forrás: kamuajans.com [2020. 04. 27.] 
tekinthetők újnak vagy egyedinek: más államokra, illetve az AKP-n kívül más török pártokra is jellemzö ez a tevékenység, csupán a retorika és az eszközök térnek el. Ezzel együtt minden államnak fontos felismernie a külső befolyásolási törekvéseket, hogy akadályozni tudja az érdekeivel ellentétes agendák érvényesülését.

Ahogyan Törökország a 2010-es évektől egyre autoriterebbé vált, úgy került előtérbe a fortélyos hatalmi eszközök alkalmazása, amely árnyékot vont Ankara korábban sikeres puha hatalmi törekvéseire az európai tásadalmakban. A rezsimbiztonsági megfontolások felerősödése a puha hatalmi képességek csökkenéséhez vezetett az EU-n belül. Eredményét tekintve ahelyett, hogy Törökország kiterjesztette volna befolyását, az sok helyen inkább visszaszorult. A nyugati államok egyre inkább kártékonynak és fenyegetőnek érzékelik a török információs befolyást. A politikai beavatkozás és a fortélyos hatalmi eszköztár szimpátia helyett török- és iszlámellenes érzéseket szül, és a korábban elért eredményeket veszélyezteti. Jó példa erre a Diyanet szerepének átalakulása: míg korábban szívesen fogadták Európában a török imámokat és a mecsetek török finanszírozását, ma annak lehetőségeit vizsgálják, hogyan tudnák a legkisebbre csökkenteni e téren is Törökország befolyását.

A fortélyos hatalmi eszközök túlsúlyba kerülése a puha hatalmi intézményrendszer mellett ugyanúgy visszaüthet a török diaszpórára is. A diaszpóraközösségeknek szükségük van olyan intézményekre, mint például a $D I ̇ T I B$, amely megszervezi a napi vallási életet. Ankara részéről pedig természetes, ha kapcsolatot akar teremteni és tartani külföldre szakadt polgáraival. Az európai törökök annak azonban már nem feltétlenül örülnek, ha a török kormány hatalompolitikai céljai által vezérelve túlzottan beavatkozik az életükbe, és nem lenne előnyös számukra, ha emiatt „harmadik hadoszlop”-ként tekintenének rájuk az EU országaiban.

\section{FELHASZNÁLT IRODALOM}

2011 Population Census - main results, [online], 2011. Forrás: nsi.bg [2020. 04. 27.]

Akyol, Mustafa: Why is Turkey reviving an Ottoman sultan?, [online], 2016. 09. 29. Forrás: Al-Monitor [2020. 04. 27.]

Bнutтo, Fatima: How Turkish TV is taking over the world, [online], 2019. 09. 13. Forrás: The Guardian [2019. 11. 13.]

Bot-like Turkish accounts complement military operation in Syria, [online], 2019. 10. 06. Forrás: Medium [2019. 11. 02.]

Bozkurt, Abdullah: Erdoğan's long arm Maarif is educating 30,000 students in 34 countries, [online], 2019. 08. 16. Forrás: Nordic Monitor [2020. 04. 27.]

Cole, J. Michael: The Hard Edge of Sharp Power. Understanding China’s Influence Operations Abroad, [online], 2018. 10. o. Forrás: MacDonald Laurier [2020. 04. 27.]

Cumhurbaşkanı Seçimi ve 27. Dönem Milletvekili Genel Seçimi Sonuçları, [online], 2018. Forrás: T.C. Yüksek Seçim Kurulu [2020. 04. 27.]

DAmHUis, Koen: “The biggest problem in the Netherlands": Understanding the Party for Freedom's politicization of Islam, [online], 2019. 07. 24. Forrás: Brookings [2020. 04. 27.]

Yurt Dışı Temsilcilikler, [online], 2020. Forrás: Diyanet İşleri Başkanlığı [2020. 04. 27.]

DoĞRU, İslam: New Yorkıta ve Parisıte FETÖ`nün gerçek yüzü anlatıldı, [online], 2019. 07. 12. Forrás: Anadolu Ajans1 [2020. 04. 27.] 
EgERESI Zoltán: A vendégmunkások hazautalásaitól a nemzetközi lobbiig: Törökország és a török diaszpóra kapcsolata, Kisebbségkutatás, 24. évf., 2015/2, 73-97. o.

Egeresi Zoltán - PÉNZvÁLTó Nikolett: Az AKP útja az elnöki rendszerről szóló népszavazásig: rezsimépítés Törökországban (2002-2017), Nemzet és Biztonság, 2017/3, 80-109. o.

Egeresi Zoltán: Mozgalom a Jogokért és Szabadságért: egy etnikai párt útja az európai liberálisokhoz, Pro Minoritate, 2009. ősz, 175-189.

Faaliyet Raporu, [online], 2017. Forrás: UETD [2020. 04. 27.]

Germany mulls introducing 'mosque tax' for Muslims, [online], 2018. 12. 26. Forrás: DW [2020. 04. 27.]

GYőRI Lóránt - KREKó Péter: Az orosz „fortélyos hatalom” felemelkedése az információs térben, Élet és Irodalom, 63. évf., 2019/19.

İletişim Başkanlığı Teşkilatı Hakkında Cumhurbaşkanlığı Kararnamesi, [online], 2018. 07. 23. Forrás: kamuajans.com [2020. 04. 27.]

KARACAN, Derya Büyüktanır: Public Diplomacy Activities of TÜSİAD and MÜSİAD During the AK Party Era, Gazi Akademik Bakış, 11. évf., 2018/23, 73-98. o. DOI: https://doi.org/10.19060/gav.503946

Maarif Általános Iskola és Gimnázium, [online], 2019. Forrás: Oktatási Hivatal [2020. 04. 27.]

Magyarország. Projektek és tevékenységek 2014-2015, [online], 2015. Forrás: TİKA [2020. 04. 27.]

Osmanen Germania: Germany bans ethnic Turkish boxer gang, [online], 2018. 07. 10. Forrás: BBC News [2020. 04. 27.]

ÖzGenç, Meltem: Top cleric delivers Friday sermon in Mardin, [online], 2016. 02. 05. Forrás: Hürriyet Daily News [2020. 04. 27.]

PÉNZvÁLTó Nikolett: Dezinformációs és külső információs befolyás Törökországban, [online], SVKK Elemzések, 2019/24. Forrás: svkk.uni-nke.hu [2020. 04. 27.]

SiskA Katalin: A Vallási Ügyek Elnökségének jogi anomáliája a Török Köztársaságban, Pro Publico Bono - Magyar Közigazgatás, 2017/3, 118-131. o.

Souli, Sarah: Turkey’s band of pro-Erdoğan hackers keep trolling Europe, [online], 2018. 03. 17. Forrás: Vice News [2020. 04. 27.]

Sunier, Thijl - Landman, Nico: Transnational Turkish Islam, Palgrave Pivot, 2014. DOI: https://doi. org/10.1057/9781137394224

TALI, Didem: An unlikely story: Why do South Americans love Turkish TV?, [online], 2016. 09. 08. Forrás: BBC News [2019. 11. 13.]

TeRkoĞLu, Barış: Saray’daki 'SETA lobisi’ni ne zaman konuşacağız?, [online], 2019. 07. 08. Forrás: Cumhuriyet [2020. 04. 27.]

ToDD, Tony: Turkish hackers avenge France’s 'genocide bill', [online], 2011. 12. 27. Forrás: France 24 [2020. 04. 27.]

Turkish TV series attract audience from 146 countries, [online], 2019. 11. 13. Forrás: Hürriyet Daily News [2019. 11. 13.]

ÜnaL, Ali: Yunus Emre Institute Head Ateş: As an element of soft power, our aim is to introduce Turkey, its culture to the world, [online], 2017. 07. 24. Forrás: Daily Sabah [2020. 04. 27.]

VAN RIPER, Harrison: Turk Hack Team and the "Netherlands Operation", [online], 2017. 03. 29. Forrás: Digital Shadows [2020. 04. 27.]

Verfassungsschutzbericht 2017, [online], 2018. Forrás: Bundesministerium für Innern, für Bau und Heimat [2020. 04. 27.]

Vidino, Lorenzo: Erdogan's Long Arm in Europe, [online], 2019. 05. 07. Forrás: Foreign Policy [2020. 04. 27.]

WAlker, Christopher - Ludwig, Jessica: From ,Soft Power' to ,Sharp Power: Rising Authoritarian Influence in the Democratic World, [online], 2017. Forrás: National Endowment for Democracy [2020. 04. 27.]

Weise, Zia: Wanted: Imams made in Germany, [online], 2019. 12. 17. Forrás: Politico [2020. 04. 27.]

WINTER, Chase: Turkish AKP politician linked to Osmanen Germania boxing gang in Germany, [online], 2017. 12. 14. Forrás: DW [2020. 04. 27.]

Winter, Chase: Turkish imam spy affair in Germany extends across Europe, [online], 2017. 02. 16. Forrás: DW [2020. 04. 27.]

Yunus Emre Enstitüsü, [online], 2020. Forrás: yee.org.tr [2020. 04. 27.] 